\title{
Analysis on optimizing tourism industry in Heilongjiang province under the perspective of all-for-one tourism
}

\author{
Zhengjie Zhu', a \\ ${ }^{1}$ Tourism and Cuisine School, Harbin University of Commerce, Harbin, Heilongjiang, China \\ a46652953@qq.com
}

Keywords: all-for-one tourism, tourism industry, Heilongjiang province.

Abstract. The development of all-for-one tourism concept is quite a good opportunity for optimizing tourism industry in Heilongjiang province which is abundant in tourism resources. It is better to make good use of tourism resources by developing specialized tourism product, cultivating new growth pole of scenic spots and planning one-stop travelling experience. It will build new space for all-for-one tourism development in Heilongjiang province.

\section{全域旅游视角下黑龙江省旅游产业升级探析 \\ 朱正杰 $1, a$ \\ 1哈尔滨商业大学旅游烹饪学院, 哈尔滨, 黑龙江, 中国 a46652953@qq.com,}

关键词: 全域旅游; 旅游产业; 黑龙江

中文摘要. 给全域旅游观念的宏观背景下, 为黑龙江旅游产业的升级转型注入的新的生命力。 作为旅游资源大省，在有效结合资源优势的同时，通过专项旅游产品开发、全新旅游景区增 长极培育, “一站式” 体验规划等方式完成新时期旅游产业的升级转型, 构建黑龙江全域旅游 发展新空间。

全域旅游构建了一种新的复合型空间，在这种新型的复合空间内将产业、文化、农业、 生态等其他价值和功能在保持原来样子的同时, 附加了旅游消费体验功能。通过深层次对黑 龙江省冰雪旅游、生态旅游、边境旅游三大特色产品开发, 精心设计专项旅游产品, 培育旅 游景区增长极, 周边辐射式建设, 进行 “一站式” 体验规划, 从而突出龙江风光特色, 通过 旅游产业升级转型，促进黑龙江旅游产业上升为“全域旅游”新高度。

\section{1. 黑龙江省旅游产业全域发展潜力分析}

黑龙江省地处我国东北部，物产丰富，幅源辽阔。在区位条件、发展环境，旅游资源等 方面具有实现全域旅游的先天优势。

\section{1. 政府高度重视旅游业发展}

黑龙江省努力实现在 “绿水青山”、“冰天雪地” 中铸就 “金山银山”，战略思维。近 年来, 黑龙江省坚持以科学发展观为指导, 以市场为导向, 以资源为基础, 实施政府主导和 旅游精品带动发展战略，大力加强旅游基本建设，东北老工业基地的振兴，政府加大对旅游 产业的扶持, 提出要把旅游产业作为第三产业的带头产业, 加快旅游业的发展, 从而带动第 三产业的发展。同时, 哈齐高铁的通车运行, 哈绥高铁的建设, 更助推黑龙江省的中西部旅 游路线的拓展, 有利于黑龙江省整体旅游品牌的整体提升; 黑龙江省旅游发展委员会的成立, 更是为全省旅游产业升级提供了机构保障; 外籍游客离境退税政策的实施, 为黑龙江省旅游 业发展注入了新的政策红利。

\section{2. 得天独厚的区位、气候条件}

黑龙江作为我国位置最北、最东, 纬度最高, 经度最东的省份。南北跨 10 个纬度带, 东 
西横跨了 14 个经度区域, 3 个湿润区。黑龙江省的北部和东部与俄罗斯边境相邻, 边境线长 3045 千米, 是亚洲陆路通往俄罗斯远东以及欧洲大陆的重要通道。土地约占全省总面积的 $24.8 \%$; 海拔高度在 300 米以上的丘陵地带约占全省 35.9\%; 平原占全省总面积的 $37.0 \%$, 平 均海拔为 50 200 米。东北部的三江平原、西部的松嫩平原, 构成我国重要的平原资源。自 然气候条件独特, 春天杜鹃花盛开, 夏天凉爽宜人, 秋天五花山色, 冬天银白世界, 冰雪多 姿。全省铁路总里程 5755.2 公里, 位居全国第二位。是东北旅游的标志性省区, 具备 “国 际旅游城市综合改革示范区”，是国家一带一路重要发展区域节点。

\section{3 遍布全省的顶级旅游资源}

黑龙江省很多自然资源堪称全国首位遍布全省的优质旅游资源为全域旅游的实现提供了 必要的开发保障。资源分布情况见表 1 所示

表 1 黑龙江省优势旅游资源

\begin{tabular}{|c|c|c|}
\hline 资源类型 & 资源优势 & 代表区域 \\
\hline 大冰雪 & $\begin{array}{l}\text { 堪称全国之最。大部分区域冬季雪量大, 雪质好, 冰冻、 } \\
\text { 降雪期达 } 5 \text { 个多月。省域内坡度、坡向适宜, 海拔 } 1000 \text { 米左 } \\
\text { 右的可建大中型滑雪场的资源点近 } 100 \text { 处, 雪塑、冰雕、冬 } \\
\text { 钓、冬泳资源也十分丰富。 }\end{array}$ & $\begin{array}{l}\text { 尚志、延寿、伊春以及五营等地素 } \\
\text { 有“林海雪原”之称 }\end{array}$ \\
\hline 大森林 & $\begin{array}{l}\text { 森林资源分布广, 属于北方寒温带森林, 可进入性强。森 } \\
\text { 林公园 } 96 \text { 处, 是拥有森林公园最多的省份, 林地面积达到 } \\
19 \text { 万平方公里, 森林覆盖率 } 43.6 \% \text {, 活立木总蓄积 } 16.5 \text { 亿立 } \\
\text { 方米, 林地面积 } 2007 \text { 万公顷。拥有亚洲最大的红松母树林, } \\
\text { 被联合国教科文组织列为世界生物圈网络成员。 }\end{array}$ & $\begin{array}{l}\text { 大小兴安岭、张广才岭、完达山等 } \\
\text { 林区 }\end{array}$ \\
\hline 大界江 & $\begin{array}{l}\text { 黑龙江是世界上最长的界江, 中俄界段就达 } 1890 \text { 公里。两 } \\
\text { 岸植被完好, 江水纯净, 是世界上为数不多的无污染河流。 }\end{array}$ & $\begin{array}{l}\text { 同江市、呼玛县、逊克县、嘉荫县、 } \\
\text { 抚远市、饶河县、绥芬河市、鹤岗 } \\
\text { 市、绥滨县、萝北县、佳木斯市 }\end{array}$ \\
\hline 大湖泊 & $\begin{array}{l}\text { 黑龙江省江河湖泊网络齐布, 有黑龙江、乌苏里江、松花 } \\
\text { 江、嫩江四大水系。 }\end{array}$ & $\begin{array}{l}\text { 最大的火山堰塞湖—镜泊湖, } \\
\text { 中俄界湖一兴凯湖, }\end{array}$ \\
\hline 大湿地 & $\begin{array}{l}\text { 天然湿地 } 434 \text { 万公顷, 占全国天然湿地面积的八分之一, 三 } \\
\text { 江平原湿地达 } 156 \text { 万公顷, 松嫩平原湿地达 } 78 \text { 万公顷, 湿地 } \\
\text { 原始点落超过 } 20 \text { 万公顷的有迎春湿地和扎龙湿地, 超过 } 10 \\
\text { 万公顷的有兴凯湖和镜泊湖湿地, 最小的原始湿地点落也 } \\
\text { 有 } 871 \text { 公顷 }\end{array}$ & $\begin{array}{l}\text { 扎龙、三江、洪河、兴凯湖、七星 } \\
\text { 河、珍宝岛、南瓮河、东方红 }\end{array}$ \\
\hline 大油田 & $\begin{array}{l}\text { 大庆市是我国最大的油田, 在国内外享有非常高的知名度。 } \\
\text { 是工业旅游开发基础同时也是爱国主义教育基地。 }\end{array}$ & $\begin{array}{l}\text { 松基三井; 乙烯装置控制中心; 铁 } \\
\text { 人纪念馆; “干打垒”式住房; }\end{array}$ \\
\hline 大熔岩 & $\begin{array}{l}\text { 境内有 } 16 \text { 个火山群, } 80 \text { 多座火山, 火山旅游资源很有特色, } \\
\text { 五大连池称为 “打开的火山教科书” 和 “天然火山博物馆”。 }\end{array}$ & $\begin{array}{l}\text { 五大连池 } \\
\text { 镜泊湖火山区 }\end{array}$ \\
\hline 大农场 & $\begin{array}{l}\text { 黑龙江省耕地资源丰富, 是中国重要的粮食产区, 拥有 } 110 \\
\text { 多个农牧场, 高科技的应用与现代农业作业在农田上, 都 } \\
\text { 是难得的旅游资源, 农业旅游发展潜力巨大。 }\end{array}$ & $\begin{array}{l}\text { 建三江、宝泉岭、红兴隆、牡丹江、 } \\
\text { 北安农场、九三农场、嫩江农场、 } \\
\text { 绥化农场、哈尔滨农场 }\end{array}$ \\
\hline 大边境 & $\begin{array}{l}\text { 东部和北部以黑龙江、乌苏里江为界河与俄罗斯毗邻, 水 } \\
\text { 陆边界长约3000多公里。中俄贸易往来密切, 中俄文化相 } \\
\text { 互交融。 }\end{array}$ & 绥芬河、黑河、东宁、抚远 \\
\hline 大文化 & $\begin{array}{l}\text { 全省共有 } 53 \text { 个少数民族, } 10 \text { 个世居少数民族, 其余 } 5 \text { 个稀有 } \\
\text { 民族人口不足万人。红色文化、抗联精神、闯关东精神、 } \\
\text { 大庆精神、铁人精神、北大荒精神等形成独特文化软实力 }\end{array}$ & $\begin{array}{l}\text { 大兴安岭山地 } \\
\text { 讷河县、同江、饶河、 } \\
\text { 杜尔伯特等地 }\end{array}$ \\
\hline 特色城镇 & $\begin{array}{l}\text { 黑龙江省拥有 } 18 \text { 个县级市、 } 45 \text { 个县、 } 1 \text { 个自治县, 旅游资源 } \\
\text { 丰富独特、生态环境优美、景观特色明显, 配套要素完备 }\end{array}$ & $\begin{array}{l}\text { 汤旺河、北极村、黑瞎子岛、海林、 } \\
\text { 虎头、大亮子河、亚布力旅游名镇 }\end{array}$ \\
\hline
\end{tabular}




\section{4 旅游产品定位已深入人心}

全域旅游是一个重大的战略思想和部署, 是区域发展战略再定位和创新。黑龙江推进全 域旅游的一个重要探索, 就是黑龙江将全域旅游作为一个全局性战略进行统筹谋划和系统推 进。在黑龙江, “黑龙江的冰天雪地也是金山银山”, “北国风光, 美在黑龙江” 这些口号已经 深入人心。发展全域旅游, 已经从黑龙江人的心里长出来, 深深扎根在这一片神奇的土地。

\section{2. 全域旅游背景下我省旅游产业升级存在的问题}

\section{1 旅游产业格局体系不清晰}

大旅游产业是指将旅游者旅游需求作为出发点, 视旅游消费为线路, 将相关的产业有效 连接, 通过实现供需对接, 辐射其他关联行业, 从而实现市场多元化需求的满足。包括旅游 制造销售业、健康服务产业、旅游地产业、民族文化产业、乡村旅游业等在内, 也包括消费 类型服务业、生产类型服务业和加工制造业等的综合产业体系。旅游资源大省黑龙江一直以 来以工、农业为支柱产业，对于第三产业的旅游服务业认识是浅薄和片面的。对于全域旅游 的理解只是停留在表层状态。旅游意识, 旅游观念相对落后。旅游没有成为龙江人生活消费 的必需选项, 因此, 省内居民对旅游的重要性认识不足, 只停留在旅游景区这一层面, 所以 出现黑龙江省基层旅游发展严重滞后的现象。

\section{2 全域旅游发展的旅游产业制度设计缺乏创新思想}

目前, 黑龙江省旅游制度体系不健全, 现行发展制度缺乏创新, 旅游制度体系发展速度 慢。改革力度不强, 缺少勇于开拓的创新精神。尤其部分地方政府在创新旅游制度方面做的 工作相对较少, 而多采用套用搬用先进地区成功模式的情况, 结果照抄照搬的结果, 往往无 法有效结合当地资源与消费需求，水土不服。造成盲目投资上马雷同的大型旅游项目，重复 建设严重，市场分析度不够，在同一市场半径内开发同质产品，最终以惨败收场。

\section{3. 旅游要素市场协调性弱}

黑龙江省在旅游市场要素组合中, 受传统观念的影响, 思维比较落后, 未处理好政府和 市场关系, 旅游产业要素自由流动性较差, 资源配置效率较低, 比例构建失衡、旅游产业体 系中旅游行业七大要素中购物及娱乐要素的发展相比其他要素较为滞后, 各要素内部的层次 及类型结构也不合理均衡。

\section{3. 全域旅游视角下我省旅游产业升级的对策建议}

\section{1. 构建大旅游产业体系格局}

在全域旅游创新的视角下, 我省旅游产业升级应从以下方面入手进行转型：一要加快旅 游与城镇建设融合发展。二要加快旅游产业与文化产业的深度融合。加大旅游与影视、演艺、 节庆、动漫产业、网络文化等业态的融合力度，做大地域文化旅游产业。三要加快旅游与第 一、第二、第三产业的融合发展。强化旅游与医疗、体育、商业、电信、养生养老等行业融 合, 着力构建健康服务业的体系。四要加快旅游与生态建设融合发展。加快推进国家公园示 范点的建设和生态旅游示范区的建设。五要加快旅游与乡村建设融合发展。六要加快旅游与 对外开放融合发展。依托黑龙江省作为我国面向俄罗斯、远东滨海新区辐射中心的地理位置 优势, 强化边境旅游、跨境旅游的作用, 努力把黑龙江建成国家扩大沿边开发开放的新高地。

\section{2 创新理念, 全域推进}

全域旅游是落实创新发展理念、推动旅游转型升级、实现新一轮跨越式发展的重要抓手, 是把一个区域当作一个旅游区推进空间全景化的系统旅游。科学规划布局是产业发展的关键 点。通过科学的规划布局把政府对旅游业发展提出的要求和市场对资源配置的重要作用相结 合，构筑旅游强省建设新基石。各级主管部门要将本地区旅游产业的空间布局、重大项目、 公共服务等要素纳入规划当中, 加强对全省旅游重大项目进度的监督和审查, 从根源上杜绝 旅游产业同质化发展和低水平重复设。要坚持全省一盘棋、上下一条心，促进区域旅游协同 发展、错位发展、联动发展, 而不是以邻为壑、单打独斗。

\section{3 优化旅游行业七要素}

全域旅游视角下, 要素市场的协调发展是旅游产业升级转型的必要保障, 要改变现有结 
构和格局, 还需要提升旅游行业七大要素的品质。从餐饮、住宿、交通、景区、购物、娱乐 项目、旅游则所建设等方面进行有针对性的升级改造。

\section{4. 开拓客源市场, 创新营销方式}

要加强对客源地的市场调研，拓宽客源市场。调整客源市场结构，形成多角化市场格局。 加强新客源市场的开拓力度, 形成多元化客源市场构成; 其次, 积极开拓高素质客源市场, 提高旅游产品文化含量, 从观光客市场到文化游市场转型, 坚持做到政府推广上企业销售相 结合、线上推广与线下销售相结合、面向专业人士与公众推广销售才结合、“走出去” 促销 与 “引进来” 相结合, 借国际旅游展一类的活动平台进一步巩固和开拓黑龙江重要客源市场。

\section{5. 推进科教兴旅, 人才创新驱动}

科技是第一生产力，要通过运用现代信息技术，大力发展智慧旅游，把握好 “互联网+” 和 “旅游+” 的机遇, 大力推行 “智慧旅游” ，促进旅游信息化升级。大力实施 “人才强旅” 战略, 通过强化旅游产学研合作, 培养形成一批旅游经营管理、旅游行政管理、旅游服务、 等高素质、专业化旅游人才队伍。进一步促进旅游教育的国际化、开放化，与知名国际旅游 院校、著名旅游集团合作，鼓励吸引更多国内外知名旅游规划、建筑设计、创意咨询等机构 来黑龙江设立分支机构; 加快旅游职业教育发展步伐, 重视人才质量培养, 提升导游队伍建 设和培训水平，让导游成为黑龙江旅游的重要 “软实力”。

\section{致谢}

本文为哈尔滨商业大学青年创新人才支持项目《全域旅游视角下县域旅游产业发展潜力 与对策研究》(2016QN028)的阶段性成果之一。

本文为哈尔滨商业大学学科项目《现代服务业支持龙江振兴发展研究》(HX2016001)的阶 段性成果之一。

本文为黑龙江省普通本科高校青年创新人才培养计划《中俄边境旅游发展现状与对策研

究》(UNPYSCT-2015065) 阶段性成果。

本文为黑龙江省哲学社科项目(16JYE03)阶段成果。

\section{References}

[1] Reichel A,Lowengart O,Milinan A. Rural tourism in Israel:Service quality and orientation ,Tourism Management, vol.21(8), pp.58-62,1999

[2] Wang Hongshu, The Study on the Development Potential of Tourism Industry in Heilonjang Province, Northeast Forestry University, vol.5, pp. 45-54, 2008.

[3] Denise Eby Konan,Limits to growth, Tourism and regional labor migration, Economic Modelling, vol.2, pp. 12-16, 2011. 